Gut, 1984, 25, 886-899

Progress report

\title{
Epidemiological aspects of Crohn's disease: a review of the literature
}

During the last 50 years, an apparently rare intestinal condition has become a common important clinical problem. Kennedy Dalziel, ${ }^{1}$ while working in the Western Infirmary, Glasgow, described nine patients with an illness which is now known as Crohn's disease. ${ }^{2}$ This disease became much more common in the 1950s and emerged as a major gastrointestinal problem with current estimates that as many as 20000 people may be affected in Britain. As the disease often afflicts young people shortly after puberty and lasts throughout life, it has important implications for individual patients and those involved in their management. Treatment, which is empirical and not curative, is largely based on the use of steroids and surgical resections, both of which carry a significant morbidity and mortality. It is not surprising that there has been substantial research endeavour to identify the cause and although viruses, bacteria, and immunological abnormalities have all been implicated, direct evidence for the role of a major causative agent is lacking. It is therefore pertinent to review epidemiological data which may give some lead in the quest for such causative factors.

\section{International differences in the occurrence of Crohn's disease}

A review of current world literature suggests that Crohn's disease is most common in North America and northern Europe, emerging in southern Europe and least common in other areas of the world. Scandinavian studies have produced the highest prevalence figures ( 75 and $54 / 10^{5}$ of the population $)^{22} 23$ while high British figures are between 26 and 56/10 612 (Table 1).

The type of health care available, particularly in Scandinavia and Great Britain may partly account for high figures from these countries. The health service is largely free and there are computerised records which would facilitate collection of epidemiological data. The type of health care cannot entirely explain the high prevalence figures, however, because comparable countries in the southern hemisphere, such as Australia, ${ }^{40}$ apparently have low figures although good data to substantiate this is lacking. The incidence of Crohn's disease in New Zealand ${ }^{35} 36$ and South Africa $^{32-34}$ is lower than in Europe despite the fact that many of their citizens are of European extraction, so that the major difference between countries is unlikely to be due to racial factors. Attempts to examine the disease in different racial groups within the same country do suggest that figures are higher in subjects of northern European origin. ${ }^{32-37}$ Prevalence figures for non-white people are less reliable for various reasons. Diarrhoea of uncertain aetiology and abdominal tuberculosis are common 
Table 1 Studies of the incidence (cases/10 $/$ year) and prevalence (cases $/ 10^{5}$ of the population) with Crohn's disease

\begin{tabular}{|c|c|c|c|c|c|}
\hline Place of study & $\begin{array}{l}\text { Inci- } \\
\text { dence }\end{array}$ & $\begin{array}{l}\text { Preval- } \\
\text { ence }\end{array}$ & Place of study & $\begin{array}{l}\text { Inci- } \\
\text { dence }\end{array}$ & $\begin{array}{l}\text { Preval- } \\
\text { ence }\end{array}$ \\
\hline Great Britain & & & Denmark & & \\
\hline Oxford $^{3}$ & $0 \cdot 8$ & 9 & Copenhagen $^{24} 25$ & $2 \cdot 7$ & 32 \\
\hline London ${ }^{4}$ & - & 13 & Finland & & \\
\hline Gloucester $^{5}$ & $1 \cdot 5$ & - & Turku ${ }^{26}$ & $0 \cdot 27$ & \\
\hline Nottingham $^{6}$ & $3 \cdot 6$ & $26 \cdot 5$ & Europe & & \\
\hline North East Scotland ${ }^{78}$ & $2 \cdot 1$ & $32 \cdot 5$ & Switzerland & & \\
\hline Clydesdale $^{9}$ & $1 \cdot 5$ & - & Basle $^{27}$ & $2 \cdot 6$ & \\
\hline Northern Ireland ${ }^{10}$ & $1 \cdot 3$ & - & Italy & & \\
\hline 1 Belfast & $3 \cdot 5$ & & Bologna ${ }^{28}$ & 0.8 & \\
\hline 2 County Down & $0 \cdot 3$ & & Spain & & \\
\hline North Tees ${ }^{11}$ & $5 \cdot 3$ & 35 & Galicia $^{29}$ & $0 \cdot 14$ & $1 \cdot 22$ \\
\hline Cardiff ${ }^{12}$ & $4 \cdot 8$ & 56 & Madrid ${ }^{30}$ & $0 \cdot 7$ & \\
\hline North America & & & Czechoslovakia & & \\
\hline Baltimore $^{13}$ & & & Northern Bohemia ${ }^{31}$ & $1 \cdot 6-2 \cdot 0$ & 12 \\
\hline White male & $2 \cdot 5$ & & South Africa & & \\
\hline White female & $1 \cdot 2$ & & Western Cape 3233 & & \\
\hline Standford University & & & Jewish & $7 \cdot 2$ & \\
\hline Palo Alto, Calif ${ }^{14}$ & - & 13 & White & 1.2 & \\
\hline USA - 15 towns study ${ }^{15}$ & $2 \cdot 4$ & & Black & $1 \cdot 3$ & \\
\hline Olmsted County, Minn ${ }^{16}$ & $6 \cdot 6$ & 106 & Pretoria $^{34}$ & & \\
\hline Sherbrooke, Quebec ${ }^{17}$ & $0 \cdot 7$ & $6 \cdot 3$ & White & $1 \cdot 1$ & \\
\hline Scandinavia & & & Black & 0.2 & \\
\hline Norway & & & New Zealand & & \\
\hline Norway ${ }^{18}$ & 1.03 & - & 1 Whole country ${ }^{35}$ & - & 49 \\
\hline Bergen $^{19}$ & $3 \cdot 5$ & - & 2 Auckland $^{36}$ & & \\
\hline Sweden & & & Caucasians & 1.8 & \\
\hline 1 Uppsala and & & & Polynesians & 0 & \\
\hline Vastmanland ${ }^{20}$ & 3 & 27 & Israel & & \\
\hline 2 Gothenburg ${ }^{21}$ & $6 \cdot 3$ & & Tel-Aviv ${ }^{37}$ & $1 \cdot 3$ & $12 \cdot 3$ \\
\hline 3 Malmö $^{22}$ & 6 & $75 \cdot 2$ & Beersheba $^{38} 39$ & 1.8 & $12 \cdot 3$ \\
\hline 4 Stockholm ${ }^{23}$ & 5 & $54 \cdot 2$ & & & \\
\hline
\end{tabular}

among such populations and in areas with a limited medical service the true incidence of Crohn's disease would be masked. Additional factors include variations in diagnostic criteria used in different countries and it was with this in mind that guidelines for diagnosis were put forward by the Organisation Mondiale de Gastroenterologie. ${ }^{41}$

Few cases have been reported from Africa. ${ }^{42}$ Similarly, there is only a single series of 44 cases from India ${ }^{43}$ and small groups of cases have been reported from Chile. ${ }^{44} 45$ There appear to be relatively low incidence figures for the East Indian ${ }^{46}$ and Asian populations ${ }^{47}$ in Britain and further studies on different racial groups in Britain may be of value in establishing the role of racial origin in the cause of disease.

The highest figures for Crohn's disease come from northern Europe and North America where the highest current figures for prevalence are 75 and $56 / 10^{5}$ of the population from Malmö in Sweden and Cardiff.

\section{Urban and rural Crohn's disease}

Studies from different parts of the world support the view that Crohn's disease is more common in towns than country areas (Table 2). This has been shown in Wales where prevalence was examined throughout the country, involving 1100 patients; ${ }^{48}$ similar findings were also made in 
Table 2 Urban-rural distribution of Crohn's disease

\begin{tabular}{|c|c|c|c|}
\hline Place & Measurement & Urban & Rural \\
\hline $\begin{array}{l}\text { Wales }{ }^{48} \\
\text { Northern Ireland }^{10}\end{array}$ & Period prevalence (cases $/ 10^{5}$ ) & $47 \cdot 6$ & 34 \\
\hline Belfast/County Down & Incidence (cases/10 $/ \mathrm{yr}$ ) & $3 \cdot 5$ & 0.29 \\
\hline Aberdeen ${ }^{7}$ & Prevalence (cases $/ 10^{5}$ ) & 49 & 29 \\
\hline Olmsted County, USA ${ }^{16}$ & Prevalence (cases $/ 10^{5}$ ) & $116 \cdot 7$ & $84 \cdot 2$ \\
\hline New Zealand ${ }^{35}$ & Mean rates/yr & 119 & 59 \\
\hline Madrid Province ${ }^{30}$ & Percentage composition & $94 \cdot 2$ & $5 \cdot 8$ \\
\hline Bologna $a^{28}$ & Percentage composition & $77 \cdot 8$ & $22 \cdot 2$ \\
\hline
\end{tabular}

Ireland, ${ }^{10}$ Scotland, ${ }^{7}$ New Zealand, ${ }^{35}$ and the $\mathrm{USA}^{16}$ with some smaller studies in Madrid ${ }^{30}$ and Bologna. ${ }^{28}$ These differences, however, have not been observed in central Sweden where the incidence is particularly high. ${ }^{20}{ }^{23}$ The differences observed in Aberdeen ${ }^{7}$ and Olmsted County, Minnesota, ${ }^{16}$ were against the background of a marked rise in incidence during the last decade, which was most marked in urban areas. Recent figures from Aberdeen which suggest a fall in incidence no longer show a difference in prevalence between urban and rural communities. ${ }^{8}$ One interpretation of these findings is that environmental changes which may be responsible for Crohn's disease affect town dwellers first and their more conservative countrymen later.

Most studies show that Crohn's disease is more common in urban than rural areas.

\section{Has the incidence of Crohn's disease changed?}

Although there were early reports of the disease last century ${ }^{49} 50$ it was not until the 1960s that attempts were made to quantify the size of the problem. Evans and Acheson ${ }^{3}$ in Oxford were among the first to review the disease in Britain and identified only 24 cases. During the subsequent 15 years studies of incidence and prevalence were reported in Britain from London, ${ }^{4}$ Gloucester, ${ }^{5}$ Cardiff, ${ }^{12}$ Nottingham, ${ }^{6}$ Aberdeen, ${ }^{7}$ Clydesdale, ${ }^{9}$ and North Tees. ${ }^{11}$ Similar techniques were used to identify patients in all centres although the studies were retrospective; prevalence ranged from 12 to as high as $55 / 10^{5} .51$

During the 1960s clinical impressions suggested that the disease was becoming more common and attempts were made to investigate this. Cardiff, ${ }^{12}$ Nottingham, ${ }^{6}$ and Aberdeen ${ }^{7}$ all showed a rise in the incidence. Figures for quinquennia 1970-75 and 1975-80 were the same in Cardiff ${ }^{52}$ and may represent a plateau although one would like to see figures for a decade to give a reliable indication of the trend in view of the considerable variation which occurs from year to year. From Aberdeen ${ }^{8}$ the figures for 1962 and 1976 for North East Scotland suggest a fall in incidence from $2 \cdot 6$ to $2 \cdot 1 / 10^{5} /$ year but one would like to see figures for a longer period. There are many difficulties in retrospective studies because the definition of disease may change. In the last 20 years the recognition of Crohn's disease limited to the colon only has contributed to this difficulty. ${ }^{53}$ In its early history, Crohn's disease was usually recognised by surgical intervention but more sophisticated radiology has made recognition of mild cases possible. 
Retrospective studies are limited by the completeness with which cases are identified, particularly where outpatients are excluded and inadequate data from early series may give a false impression of change in incidence.

Although these considerations probably contribute to an apparent rise in incidence, they do not completely explain it. The Cardiff studies show that milder cases have not contributed to the increase in incidence. ${ }^{12}$ There has been a steady rise in the number of cases recognised at surgery and mortality expressed as standardised mortality ratio for Crohn's disease has not fallen in the same period $;^{54}$ both these factors suggest that the increased incidence is not because of recognition of mild cases.

Changes in incidence may help to identify causative factors. The possible protective effect of breast milk has been considered; Heller's ${ }^{55}$ work is of interest for bottle feeding has decreased in northern Europe but increased in developing countries ${ }^{56}$ during the last decade. If breast feeding has a protective effect we might expect a decline in the incidence of Crohn's disease in northern Europe and the USA after a latent period of 20 years or so.

The incidence of Crohn's disease has risen during the last 25 years in northern Europe with high figures of $6 / 10^{5} /$ year in Malmö, Southern Sweden.

\section{Infectious aetiology}

Considerable laboratory endeavours have been directed towards isolation of an infectious agent in Crohn's disease and these will not be discussed here. Although epidemiology has traditionally been concerned with the discovery of causes and modes of transmission of infection, it is incongruous that few studies have looked at this aspect of Crohn's disease.

There have been several studies from Nottingham. ${ }^{57}$ In the first the date and place of domicile and work at the time symptoms began was obtained for 260 patients in the city. There is no evidence of clustering of cases in time or space. These negative findings, however, do not completely rule out the possibility of an infectious agent with a long latent period, or an abnormal response to some childhood infection. In the second a different approach was used in which patients were compared with age and sex matched controls and the 'effective contact' between members of each group was measured. There was no greater contact between patients with Crohn's disease than between healthy controls. Neither study has given encouragement to the idea that Crohn's disease is infectious.

Three studies have sought evidence for a transmissible agent in Crohn's disease by looking at doctors and nurses who have frequent contact with affected patients.

In Goodman et al's study 998 members of the American Gastroenterological Association had responded to a questionnaire distributed to 1755 doctors; eight had either ulcerative colitis or Crohn's disease (combined prevalence of $810 / 10^{5}$ population). This high prevalence was attributed to age structure and bias in returning the questionnaire, selection of career, and possibly an increased diagnostic accuracy.

Two antibodies which occur with high frequency in patients may be markers of infection and have been studied. No evidence was found for an 
increased incidence of lymphocytotoxic antibody in American gastroenterologists, ${ }^{59}$ and this is a similar finding to the absence of serum antibodies to anaerobic coccoid rods in British doctors. ${ }^{60}$ Similarly there is no evidence that nurses have an increased risk of the disease. ${ }^{61}$

There is no evidence from epidemiological studies for transmission or spread of an infective agent in the causation of Crohn's disease.

\section{Genetic factors in Crohn's disease}

There are only two particular studies ${ }^{5162}$ measuring the prevalence of Crohn's disease in first degree relatives of patients. In Cardiff, ${ }^{51}$ details of family structure were obtained from 139 of the surviving 147 patients in 1979. The prevalence of Crohn's disease in siblings was $1602 / 10^{5}$ (based on seven siblings with Crohn's disease disease in a population of 437), compared with a prevalence of $56 / 10^{5}$ for all residents in the city of Cardiff. No affected parents or children were reported in the group. A similar study in Leiden ${ }^{62}$ gave a prevalence of $1597 / 10^{5}$ in siblings. The studies were not strictly comparable for the Cardiff data were based on patients resident in the city rather than the hospital population as in Leiden. The studies show that Crohn's disease may be 30 times more common in siblings compared with the general population and 13 times more common in all first degree relatives (Table 3 ). This increased risk factor does not suggest inheritance by a simple Mendelian inheritance with high penetrance but suggests several factors may be involved.

Information from other areas suggest a genetic predisposition for Crohn's disease. The association between Crohn's disease and ankylosing spondylitis is one $;^{63} \mathrm{McBride}$ et al $^{64}$ examined 560 patients with ankylosing spondylitis and a diagnosis of Crohn's disease was made in four cases (expected number, $0 \cdot 3$ ). Patients with Crohn's disease also appeared to have a greater occurence of ankylosing spondylitis than would have appeared by chance. Some evidence comes from attempts to test an association with atopic disease $;{ }^{65} 66$ these have shown a significantly high prevalence of eczema among both patients and first degree relatives.

Family studies can be of particular value in the assessment of factors which may operate early in life and predispose to the disease. Twin studies are often valuable in this context, but to date less than 20 affected twins have been reported. ${ }^{67}$ The number of twins in Britain ${ }^{68}$ with at least one

Table 3 Prevalence of Crohn's disease in family members

\begin{tabular}{|c|c|c|c|c|c|c|}
\hline & \multicolumn{3}{|l|}{ Cardiff } & \multicolumn{3}{|l|}{ Leiden } \\
\hline & $\begin{array}{l}\text { Cases of } \\
\text { Crohn's } \\
\text { disease } \\
\text { (no) }\end{array}$ & $\begin{array}{l}\text { Population } \\
\text { at risk }\end{array}$ & $\begin{array}{l}\text { Prevalence } \\
\left(/ 10^{5}\right)\end{array}$ & $\begin{array}{l}\text { Cases of } \\
\text { Crohn's } \\
\text { disease } \\
\text { (no) }\end{array}$ & $\begin{array}{l}\text { Population } \\
\text { at risk }\end{array}$ & $\begin{array}{l}\text { Prevalence } \\
\left(/ 10^{5}\right)\end{array}$ \\
\hline Residents & 156 & 280100 & 56 & - & - & - \\
\hline Parents & 0 & 278 & 0 & 4 & 758 & 528 \\
\hline Siblings & 7 & 437 & 1602 & 20 & 1252 & 1597 \\
\hline Children & 0 & 152 & 0 & 3 & - & - \\
\hline
\end{tabular}


affected member may be as high as 350 and the discrepancy between the two figures is not easily explained. HLA studies are in progress in several centres. ${ }^{6970}$ There is no evidence for a particular genetic marker predisposing to Crohn's disease, but $80 \%$ of patients lack DR2 compared with only $64 \%$ of healthy controls. Individuals possessing DR2 had a $40 \%$ less chance of developing inflammatory disease.

There is a small genetic predisposition to Crohn's disease which increases the risk by 30 in siblings and only by: 13 in all first degree relatives.

\section{Incidence in Jews}

In 1960 Acheson $^{71}$ showed that Crohn's disease was particularly common in Jewish American veterans but recognised that this may reflect different social attitudes to hospital admission rather than a real difference in incidence. Subsequent clinical series reported a high frequency among Jews, especially in South America where Crohn's disease is rare. ${ }^{44} 4572$ High prevalence figures have been reported uniformly from western Europe and South Africa but these are not supported by studies in Tel Aviv and Beersheba (Table 4).

The view that Crohn's disease is more common among Jews than other groups is based on small numbers and may not be true.

\section{Diet and Crohn's disease}

Dietary studies are fraught with difficulties and cannot reflect pre-illness diet. Patients' attempts to record eating habits before diagnosis are

Table 4 Crohn's disease in Jewish populations

\begin{tabular}{|c|c|c|c|}
\hline \multirow[b]{2}{*}{ Centre } & \multicolumn{3}{|c|}{ Crohn's disease } \\
\hline & $\begin{array}{l}\text { Cases } \\
\text { (no) }\end{array}$ & $\begin{array}{l}\text { Incidence } \\
\left.\text { (cases } / 10^{5} / y r\right)\end{array}$ & $\begin{array}{l}\text { Prevalence } \\
\left.\text { (cases } / 10^{5}\right)\end{array}$ \\
\hline Baltimore $^{13 *}$ & 28 & $3 \cdot 5$ & 14 \\
\hline \multicolumn{4}{|l|}{ Western Cape } \\
\hline $1970-74^{32}$ & 24 & $2 \cdot 8$ & 200 \\
\hline $1975-79^{33}$ & 20 & $7 \cdot 2$ & - \\
\hline Basle $^{27}$ & 1 & $3 \cdot 6$ & $35 \cdot 7$ \\
\hline Nottingham $^{74}$ & 2 & - & 100 \\
\hline Malmö ${ }^{22}$ & 5 & 25 & 400 \\
\hline Stockholm ${ }^{73}$ & 24 & 10 & 200 \\
\hline Tel-Aviv ${ }^{37}$ & 44 & $1 \cdot 3$ & $12 \cdot 3$ \\
\hline Born in Europe and America & 26 & - & $20 \cdot 6$ \\
\hline Israeli born & 12 & - & 7.9 \\
\hline Born in Asia and Africa & 5 & - & $8 \cdot 2$ \\
\hline Ashkenazim & 37 & - & $16 \cdot 7$ \\
\hline Sephardim & 5 & - & $4 \cdot 2$ \\
\hline Beersheba ${ }^{39}$ & - & - & $12 \cdot 3$ \\
\hline Immigrants $\dagger$ & - & - & $22 \cdot 75$ \\
\hline Israeli bornt & - & - & $16 \cdot 43$ \\
\hline
\end{tabular}


unreliable and their motivation will differ from controls. Studies which involve patients recording and weighing food for several days often produce changes and such studies are probably no more accurate than those dependent on a simple questionnaire.

The relationship between diet and Crohn's disease is one which has aroused interest since earliest descriptions of the condition. The possibility that a dietary antigen provokes a granulomatous reaction is attractive and an early suggestion was silica which produces a granulomatous reaction in dogs. ${ }^{75}$ The association between milk consumption and ulcerative colitis in some patients was first reported by Wright and Truelove ${ }^{76}$ but Warthin ${ }^{77}$ later reported that American troops with Crohn's disease had a remission from their symptoms while taking combat rations which excluded milk products. This report, however, was anecdotal and no attempt was made to validate the findings.

After a decade of silence, James ${ }^{78}$ reawakened interest when he reported an association between the disease and cornflakes. Studies from Oxford ${ }^{79}$ Bristol, $^{80}$ and Cardiff ${ }^{81}$ failed to confirm the high intake of cornflakes but drew attention to several German studies ${ }^{82} 83$ which recorded sugar and fibre consumption.

SUGAR

In 1976 two German studies from Marburg ${ }^{82}$ and Düsseldorf ${ }^{83}$ reported an increased sugar consumption by patients with Crohn's disease. Martini and Brandes $^{82}$ studied 63 patients and controls; patients ate $116 \mathrm{~g}$ /day refined sugar at the time of study and $177 \mathrm{~g} /$ day before the condition was diagnosed, compared with $74 \mathrm{~g} /$ day by controls. Miller et al ${ }^{83}$ reported similar findings from Düsseldorf. The main criticism of these and other dietary studies is the inaccuracy of information related to the time of diagnosis. The findings, however, have been confirmed from Cardiff, ${ }^{81} 84{ }^{85}$ Bristol, ${ }^{86}$ Tel Aviv, ${ }^{87}$ and Orebro, Sweden, ${ }^{88}$ although their significance remains obscure. In Cardiff and Bristol the high sugar consumption cannot be attributed to the effect of longstanding illness with diarrhoea, for it was not seen in patients with ulcerative colitis. ${ }^{84} 89$ Recent work in Orebro ${ }^{88}$ however, may not support this. All other studies suggest that sugar consumption is high initially and falls subsequently (Table 5). A combined study of newly diagnosed cases from Cardiff and Birmingham ${ }^{85}$ also showed that patients had a high sugar consumption at the time of interview.

The increased consumption of sugar is independent of cultural differences and has been described in various Anglo Saxon and Nordic groups together with Ashkenazi and Sephardic Jews. ${ }^{87}$ In the Israeli groups the difference was independent of immigration status. The significance of dietary studies, however, remains uncertain. Three recent attempts to relate the increased consumption to differences in taste sensitivity have failed to explain these findings. ${ }^{91-93}$

Patients may need more sugar than healthy people but two preliminary reports suggest that patients actually benefit from a low sugar intake. ${ }^{94} 95$

DIETARY FIBRE

The association between fibre consumption and Crohn's disease is uncertain. There have been three main assessments from Wurzburg, ${ }^{90}$ 
Table 5 Consumption of sugar by patients with Crohn's disease

\begin{tabular}{|c|c|c|c|}
\hline \multirow[b]{3}{*}{ Study centre } & \multicolumn{3}{|c|}{ Consumption of sugar (g) } \\
\hline & \multicolumn{2}{|l|}{ Patients } & \multirow[b]{2}{*}{ Controls } \\
\hline & At diagnosis & $\begin{array}{l}\text { At time of } \\
\text { interview }\end{array}$ & \\
\hline Marburg ${ }^{\mathrm{X2}}$ & 177 & 116 & 74 \\
\hline Düsseldorf ${ }^{\text {*3 }}$ & 150 & 115 & 55 \\
\hline Wurzburg ${ }^{y_{1}}$ & & 156 & 91 \\
\hline Orebro ${ }^{88^{\circ}}$ & - & 89 & 64 \\
\hline Cardiff ${ }^{34}$ & 60 & 52 & 29 \\
\hline Bristol $^{86}$ & - & 122 & 65 \\
\hline Tel-Aviv ${ }^{87}$ & 314 & 269 & 200 \\
\hline
\end{tabular}

The consumption of sugar was assessed by different techniques and using different anlytical tables in the various centres. The definition of refined sugar is also variable from study to study.

The consumption of sugar was significantly different between patients and controls at the time of diagnosis and at the time of interview.

Bristol, ${ }^{86}$ and Cardiff ${ }^{85}$ respectively. The outcome of these could not be more dissimilar; in Wurzburg ${ }^{90}$ patients ate more, in Bristol ${ }^{86}$ less, and in Cardiff ${ }^{85}$ they ate the same quantity of fibre. It therefore seems unlikely that fibre plays an important role in the development of Crohn's disease.

\section{Breast and bottle feeding in childhood}

Epidemiological studies on breast feeding have come from Stockholm ${ }^{23} 73$ and show that patients with Crohn's disease were breast fed for shorter periods than healthy controls but the difference was only 1.17 months. Whorwell et al ${ }^{96}$ were unable to show such an association in a considerably smaller study. It is possible that pathogenic infections in infancy may become manifest later in life as Crohn's disease; if this were true then breast feeding could give passive protection.

The only consistent and rather surprising finding from dietary studies is the high sugar consumption in patients compared with healthy controls; this is probably a secondary factor rather than one of primary significance.

\section{Mortality}

Mortality figures reflect the severity of disease in different groups of patients. Longitudinal studies from Cardiff ${ }^{54}$ and Stockholm ${ }^{23}$ have shown no change in survival during the last 30 years although surgical and medical treatment has probably made life more tolerable. In most centres mortality is twice the expected figure for the general populations, but international comparisons ${ }^{40}$ of such data are of limited value because of differences in patient identification.

Several centres have reported their experience with Crohn's disease over many years and assessed the mortality of their patients. Standardised mortality rates allow comparisons to be made between such centres (Table 6). Studies based on hospital series are from centres with a special interest in Crohn's disease which often attract ill patients who may contribute to a higher mortality; ${ }^{97}$ groups who appear at particular risk in these centres 
Table 6 Mortality in Crohn's disease

\begin{tabular}{lllll}
\hline Centre & $\begin{array}{l}\text { Period of } \\
\text { study }\end{array}$ & $\begin{array}{l}\text { Patients } \\
(\text { no })\end{array}$ & $\begin{array}{l}\text { Deaths } \\
\text { (no) }\end{array}$ & $\begin{array}{l}\text { Standardised } \\
\text { mortality } \\
\text { rates }\end{array}$ \\
\hline Tubingen $^{49}$ & $1972-78$ & 256 & 12 & $3 \cdot 8$ \\
Leiden $^{1(x)}$ & $1934-72$ & 226 & 21 & $3 \cdot 5$ \\
Stockholm $^{23}$ & $1955-74$ & 826 & 65 & $1 \cdot 9$ \\
Copenhagen $^{47 *}$ & $1964-76$ & 297 & 36 & $5 \cdot 6$ \\
Oxford $^{101 *}$ & $1938-70$ & 221 & 31 & $2 \cdot 2$ \\
Cardiff $^{(4+}$ & $1934-76$ & 218 & 40 & $2 \cdot 2$ \\
Birmingham $^{102}$ & $1941-76$ & 513 & 102 & 2 \\
Bridgend $^{48_{+}}$ & $1961-80$ & 79 & 5 & $1 \cdot 3$ \\
Olmsted County (USA) $^{16_{+}}$ & $1935-75$ & 103 & 13 & $1 \cdot 7$ \\
\hline
\end{tabular}

Mortality rates reported in various centres.

* Mortality rates were significantly increased at these centres by referral of ill patients.

+ Studies at these centres were based on population data.

may reflect this bias. Population based studies such as the one from Cardiff, ${ }^{54}$ Stockholm, ${ }^{23}$ Bridgend, ${ }^{98}$ and Olmsted County ${ }^{16}$ identify the patients at greatest risk without prior selection. Groups with a high mortality include young patients under 20 years of age at the time of diagnosis, those with extensive disease, particularly affecting small bowel, and newly diagnosed patients. If mortality figures are to improve, then treatment in these particular groups should be more effective.

In Birmingham the effect of treatment on mortality has been examined where the standardised mortality rate was found to be $2 \cdot 4 .{ }^{103}$ When the effect of steroids was considered, the standardised mortality rate in that groups of patients increased to 3.6 compared with 1.8 among patients not receiving steroids, although this effect may have been because of severity of the disease.

The standardised mortality ratio is twice normal in most series but is especially high in young patients or those with extensive disease.

\section{Crohn's disease and cancer}

Patients with Crohn's disease have an increased risk of developing carcinoma of the gastrointestinal tract. Weedon et al ${ }^{104}$ has reviewed 449 patients with Crohn's disease who were treated at the Mayo Clinic. Twelve developed cancer; in seven cases the colon was affected and in one the rectum; the probability of developing colorectal cancer over 20 years was estimated at $2 \cdot 8 \%$. Although this appears to be small, the number of cases was 20 times greater than would have been expected in an age and sex matched population from Connecticut. The group of patients considered, however, came from all over North America. A recent study of 513 patients from Birmingham ${ }^{102}$ reported only nine deaths (expected, 4 ) and suggested that the risk was much less, although it probably increases with longstanding disease which may be particularly relevant after bypass surgery. There is no support for an extensive programme of routine screening for carcinoma of the colon in patient with Crohn's disease.

There is a slightly greater risk of the patient with Crohn's disease developing carcinoma. 
Crohn's disease has remained an enigma since its earliest description and despite 50 years of intensive investigation it is still unclear whether autoimmunity, infection, or toxic environmental agents are the major causative factors; even the role of genetic susceptibility is uncertain. Diet and events in childhood may both be important in the aetiology of the condition. Simply to assume that all of these factors play a role is to avoid the issue and withdraw from attempting to establish the cause.

After 70 years of endeavour in many different fields we can only echo the words of Kennedy Dalziel ${ }^{1}$ when he wrote, 'I can only regret that the aetiology of the condition remains in obscurity, but I trust that 'ere long further consideration will clear up the difficulty'.

Queen's Medical Centre,

J F MAYBERRY AND J RHODES

Nottingham, and

University Hospital of Wales, Cardiff.

\section{References}

1 Dalzeil TK. Chronic interstitial enteritis. $\mathrm{Br}$ Med J 1913; 2: 1068-70.

2 Crohn BB, Ginsburg L, Oppenheimer GD. Regional ileitis. A pathologic and clinical entity. JAMA 1932; 99: 1323-9.

3 Evans JG, Acheson ED. An epidemiological study of ulcerative colitis and regional enteritis in the Oxford area. Gut 1965; 6: 311-24.

4 Wright JT. The prevalence of Crohn's disease in an East London Borough. 4th World Congress of Gastroenterology. Advance Abstracts p 389, 1970.

5 Tresadern JC, Gear MWL, Nicol A. An epidemiological study of regional enteritis in the Gloucester area. Br J Surg 1973; 60: 366-8.

6 Miller DS, Keighley AC, Langman MJS. Changing patterns in epidemiology of Crohn's disease. Lancet 1974; 2: 691-3.

7 Kyle J. An epidemiological study of Crohn's disease in North East Scotland. Gastroenterology 1971; 61: 826-33.

8 Kyle J, Stark G. Fall in the incidence of Crohn's disease. Gut 1980; 21: 340-3.

9 Smith IS, Young S, Gillespie G, O'Connor J, Bell JR. Epidemiological aspects of Crohn's disease in Clydesdale, 1961-1970. Gut 1975; 16: 62-7.

10 Humphreys WG, Parks TG. Crohn's disease in Northern Ireland - a retrospective study of 159 cases. Irish J Med Sci 1975; 144: 437-46.

11 Devlin HB, Datta D, Dellipiani AW. The incidence and prevalence of inflammatory bowel disease in North Tees Health District. World J Surg 1980; 4: 183-93.

12 Mayberry JF, Rhodes J, Hughes LE. Incidence of Crohn's disease in Cardiff between 1934 and 1977. Gut 1979; 20: 602-8.

13 Monk M, Mendeloff AI, Siegel CI, Lilienfeld A. An epidemiological study of ulcerative colitis and regional enteritis among adults in Baltimore. 1. Hospital incidence and prevalence, 1960 to 1963 . Gastroenterology 1967; 53: 198-210.

14 Gelpi A. Inflammatory bowel disease among college students. Western J Med 1978; 129: 369-73.

15 Garland CF, Lilienfeld AM, Mendeloff AI, Markowitz JA, Terrell KB, Garland FC. Incidence rates of ulcerative colitis and Crohn's disease in fifteen areas of the United States. Gastroenterology 1981; 81: 1115-24.

16 Sedlack RE, Whisnant J, Elveback LR, Kurland LT. Incidence of Crohn's disease in Olmsted County, Minnesota, 1935-1975. Am J Epidemiol 1980; 112: 759-63.

17 Nootens J, Devroede G. Frequencé de l'enterite regionale dans les cantons de l'Est. Union Med Can 1972; 101: 1138-40.

18 Myren J, Gjone E, Hertzberg JN, Rygvold O, Semb LS, Fretheim B. Epidemiology of ulcerative colitis and regional enterocolitis (Crohn's disease) in Norway. Scand J Gastroenterol 1971; 6: 511-4. 
19 Skarstein A, Arnesjö B, Burhol P et al. The incidence of ulcerative colitis and Crohn's disease in an urban population. Scand J Gastroenterol 1982; 17: 349.

20 Norlen BJ, Krause U, Bergman L. An epidemiological study of Crohn's disease. Scand J Gastroenterol 1970; 5: 385-90.

21 Kewenter J, Hulten L, Kock NG. The relationship and epidemiology of acute terminal ileitis and Crohn's disease. Gut 1974; 15: 801-4.

22 Brahme F, Lindstrom C, Wenckert A. Crohn's disease in a defined population. An epidemiological study of incidence, prevalence, mortality and secular trends in the city of Malmö, Sweden. Gastroenterology 1975; 69: 342-51.

23 Hellers G. Crohn's disease in Stockholm County 1955-1974. A study of epidemiology, results of surgical treatment and long-term prognosis. Acta Chir Scand 1979; suppl 490.

$24 \mathrm{Hoj}$ L, Brix Jensen P, Bonnevie O, Riis P. An epidemiological study of regional enteritis and acute ileitis in Copenhagen County. Scand J Gastroenterol 1973; 8: 381-4.

25 Binder V, Both H, Hansen PK, Hendriksen C, Kreiner S, Torp-Pedersen K. Incidence and prevalence of ulcerative colitis and Crohn's disease in the County of Copenhagen 1962-1978. Gastroenterology 1982; 83: 563-8.

26 Havia T, Thomasson B. Crohn's disease. A follow-up study. Acta Chir Scand 1972; 138: 844-7.

27 Fahrlander H, Baerlocher Ch. Clinical features and epidemiological data on Crohn's disease in the Basle area. Scand J Gastroenterol 1971; 6: 657-62.

28 Lanfranchi GA, Michelini A, Brignola C, Campieri M, Cortini C, Marzio L. Uno studio epidemiologico sulle malattie inflammatorie intestinali nella provincia di Bologna. $G$ Clin Med 1976; 57: 235-45.

29 Ochoa R. Epidemiologia. In: 'Simposio sobre La enfermedad de Crohn en Galicia' by Fiol M, Ochoa R, Perez P, Albrades, G, Lesquereux P, Villaneuva P. Rev Esp Enferm Apar Dig 1977; 50: 469-82.

30 Paredes JG, Garcia JMP. Crohn's disease in the central area of Spain. In: Peña AS, Weterman IT, Booth CC, Strober W, eds. Developments in gastroenterology. 1. Recent advances in Crohn's disease. The Hague: Martinus Nijhoff, 1981: 168-73.

31 Bitter J, Zuvacova J. Crohnova choroba v severoceskem kraji. Cesk Gastroenterol Vyz 1981; 35: 137-44.

32 Novis BH, Marks IN, Bank S, Louw JH. Incidence of Crohn's disease at Groote Schuur Hospital during 1970-1974. S Afr Med J 1975; 49: 693-7.

33 Wright JP, Marks IN, Jameson C, Garisch JAM, Burns DG, Kottler BR. The Cape Town experience of Crohn's disease. In: Lee ECG, ed. Crohn's workshop. A global assessment of Crohn's disease. London: H M \& M Heyden, 1981: 95-100.

34 Mieny CJ, Laage NJ, Simson IW. Crohn's disease in Pretoria. In: Lee ECG, ed. Crohn's workshop. A global assessment of Crohn's disease. London: H M \& M Heyden, 1981: 101-6.

35 Couchman KG, Wigley RD. The distribution of the systemic connective tissue diseases; ulcerative colitis and Crohn's disease in New Zealand: an analysis of hospital admission statistics. $N Z$ Med J 1971; 74: 231-3.

36 Tasman-Jones C, Eason R, Lee SP. Inflammatory bowel disease - ethnic variations in Auckland, New Zealand. Scand J Gastroenterol 1982; 17: 350.

37 Rozen P, Zonis J, Yekutiel P, Gilat T. Crohn's disease in the Jewish population of Tel-Aviv-Yafo. Gastroenterology 1979; 76: 25-30.

38 Krawiec J, Odes HS, Lasry Y, Weitzman S. Crohn's disease in Beer-Sheba, Israel: demographic and clinical aspects. [Abstracts.] International Symposium on Inflammatory Bowel Diseases. Jerusalem: Hebrew University and Israeli Gastroenterological Society, 1981: 37.

39 Odes HS, Krawiec J, Weitzman S. Prevalence of Crohn's disease in Israel. N Engl J Med 1982; 306: 750-1.

40 Newcombe RG, Mayberry JF, Rhodes J. An international study of mortality from inflammatory bowel disease. Digestion 1983; 24: 73-8.

41 Myren J, Bouchier IAD, Watkinson G, De Dombal FT. Inflammatory bowel disease, an OMGE Survey. In Studies co-ordinated by the Research Committee of the Organisation Mondiale de Gastroenterologie. Scand J Gastroenterol 1979; 14: 1-29.

42 Segal I, OuTim L, Hamilton DG, MannellA. The Baragwanath experience of Crohn's disease and intestinal tuberculosis in the Black population. Lee ECG, ed. Crohn's workshop. A global assessment of Crohn's disease. London: H M \& M Heyden, 1981: 107-15.

43 Gupta RS, Chatterjee AK, Roy R, Ghosh BN. A review of the results of treatment of 44 
cases of Crohn's disease. Indian J Surg 1962; 24: 797-8(05.

44 Castillo HC. Enteritis regional (enfermedad de Crohn). Arch Soc Ciruj Hosp Santiago de Chile 1959; 11: 751-61.

45 Quintana C, Diaz F, Croxatto H, Montero E. Crohn's disease in a Chilean University Hospital. Gastroenterology 1978; 74: 1141.

46 O'Donoghue DP, Clark ML. Inflammatory bowel disease in West Indians. Br Med J 1976; 2: 796.

47 Burke GJ, Zafar SA. Problems in distinguishing tuberculosis of bowel from Crohn's disease in Asians. $\mathrm{Br}$ Med J 1975; 4: 395-7.

48 Mayberry JF, Rhodes J, Newcombe RG. Crohn's disease in Wales, 1967-76; an epidemiological survey based on hospital admissions. Postgrad Med J 1980; 56: 336-41.

49 Fielding JF. Dalziel's (Crohn's) disease. An historical review. History Med 1972; 4: 20-3.

50 Kyle J. Crohn's disease. London: Heinemann, 1972.

51 Mayberry JF, Rhodes J, Newcombe RG. Familial prevalence of inflammatory bowel disease in relatives of patients with Crohn's disease. Br Med J 1980; 1: 84.

52 Harries AD, Baird A, Rhodes J, Mayberry JF. Has the rising incidence of Crohn's disease reached a plateau? $\mathrm{Br}$ Med J 1982; 284: 235.

53 Lockhart-Mummery HE, Morson BC. Crohn's disease (regional enteritis) of the large intestine and its distinction from ulcerative colitis. Gut 1960; 1: 87-105.

54 Mayberry JF, Newcombe RG, Rhodes J. Mortality in Crohn's disease. Q J Med 1980; 49: 63-8.

55 Hellers G. Some epidemiological aspects of Crohn's disease in Stockholm County, 1955-1979. In: Peña AS, Weterman IT, Booth CC, Strober W, eds. Developments in gastroenterology. 1. Recent advances in Crohn's disease. The Hague: Martinus Nijhoff, 1981: 158-62.

56 McCann M, Liskin LS, Piotrow PT, Rinehart W, Fox G. Breast-feeding, fertility and family planning. Population Rep 1981; 9: 525-75.

57 Miller DS, Keighley AC, Smith PG, Hughes AD, Langman MJS. Crohn's disease in Nottingham: a search for time-space clustering. Gut 1975; 16: 454-7.

58 Miller DS, Keighley AC, Smith PG, Hughes AO, Langman MJS. A case control method for seeking evidence of contagion in Crohn's disease. Gastroenterology 1976; 71: 385-7.

59 Goodman MJ, Strickland RG, Kirsner JB. Inflammatory bowel disease and lymphocytotic antibody in members of the American Gastroenterological Association. Gastroenterology 1979; 76: 1140.

60 Mayberry J, Rhodes J, Matthews N, Wensinck F. Serum antibodies to anaerobic coccoid rods in patients with Crohn's disease or ulcerative colitis, and in medical and nursing staff. Br Med J 1981; 282: 108.

61 Mayberry JF, Newcombe RG. Are nurses at an increased risk of developing inflammatory bowel disease? Digestion 1981; 22: 150-4.

62 Weterman IT, Peña AS. Family occurrences in Dutch patients with Crohn's disease. Scand J Gastroenterol 1982; 17: 354.

63 McConnell RB. Genetics of Crohn's disease. Clin Gastroenterol 1972; 1: 321-34.

64 McBride JA, King MJ, Baikie AG, Crean GP, Sircus W. Ankylosing spondylitis and chronic inflammatory diseases of the intestines. Br Med J 1963; 2: 483-6.

65 Hammer B, Ashurst P, Naish J. Diseases associated with ulcerative colitis and Crohn's disease. Gut 1968; 9: 17-21.

66 Pugh SM, Rhodes J, Mayberry JF, Roberts DL, Heatley RV, Newcombe RG. Atopic disease in ulcerative colitis and Crohn's disease. Clin Allergy 1979; 9: 221-3.

67 Klein GL, Ament ME, Sparkes RS. Monozygotic twins with Crohn's disease: a case report. Gastroenterology 1980; 79: 931-3.

68 Mayberry JF, Dew MJ, Morris JS. Monozygotic twins with ulcerative colitis. Postgrad Med J 1982; 58: 112-6.

69 Burnham WR, Gelsthorpe K, Langman MJS. HLA-D related antigens in inflammatory bowel disease. In: Peña AS, Weterman IT, Booth CC, Strober W, eds. Developments in gastroenterology. 1. Recent advances in Crohn's disease. The Hague: Martinus Nijhoff, 1981: 192-6.

70 Biemond I, Weterman IT, Van Rood JJ, Klasen EC, Meera Khan P, Peña S. Search for genetic markers associated with Crohn's disease in the Netherlands. In: Peña AS, Weterman IT, Booth CC, Strober W, eds. Developments in gastroenterology. 1. Recent advances in Crohn's disease. The Hague: Martinus Nijhoff, 1981: 197-203.

71 Acheson ED. The distribution of ulcerative colitis and regional enteritis in United States Veterans with particular reference to the Jewish religion. Gut 1960; 1: 291-3. 
72 Faustino-Porto JA. Crohn's disease in Brazil: a newcomer in a parasitic field. In: Lee ECG, ed. Crohn's workshop. A global assessment of Crohn's disease. London: H M \& M Heyden, 1981: 127-35.

73 Hellers G. Crohn's disease in Stockholm County. In: Lee ECG, ed. Crohn's workshop. A global assessment of Crohn's disease. London: H M \& M Heyden, 1981: 85-91.

74 Keighley AC, Miller DS. Hughes AO, Langman MJS. The demographic and social characteristics of patients with Crohn's disease in the Nottingham area. Scand J Gastroenterol 1976; 11: 293-6.

75 Chess S. Chess D. Olander G, Benner W, Cole WH. Production of chronic enteritis and other systemic lesions by ingestion of finely divided foreign material. Surgery 1950; 27: 221-34.

76 Wright R. Truelove SC. A controlled therapeutic trial of various diets in ulcerative colitis. Br Med J 1965; 2: 138-41.

77 Warthin TA. Some epidemiological observations on the aetiology of regional enteritis. Trans Am Clin Climatol Assoc 1969; 80: 116-24.

78 James AH. Breakfast and Crohn's disease. Br Med J 1977; 1: 943-5.

79 Rawcliffe PM. Truelove SC. Breakfast and Crohn's disease - I. Br Med J 1978; 2: $539-40$.

80 Archer LNJ, Harvey RF. Breakfast and Crohn's disease - II. Br Med J 1978; 2: 540.

81 Mayberry JF, Rhodes J, Newcombe RG. Breakfast and dietary aspects of Crohn's disease. Br Med J 1978; 2: 1401.

81 Martini GA. Brandes JW. Increased consumption of refined carbohydrates in patients with Crohn's disease. Klin Wochenschr 1976; 54: 367-71.

83 Miller B. Fervers F, Rohbeck R, Strohmeyer G. Zuckerkonsum bei patienten mit morbus Crohn. Verh Dtsch Ges Inn Med 1976; 82: 922-4.

84 Mayberry JF, Rhodes J, Newcombe RG. Increased sugar consumption in Crohn's disease. Digestion 1980; 20: 323-6.

85 Mayberry JF. Rhodes J, Allen R et al. Diet in Crohn's disease: two studies of current and previous habits in newly diagnosed patients. Dig Dis Sci 1981; 26: 444-8.

86 Thornton JR, Emmett PM, Heaton KW. Diet and Crohn's disease: characteristics of the pre-illness habit. $\mathrm{Br}$ Med J 1979; 2: 762-4.

87 Silkoff K, Hallak A, Yegena L et al. Consumption of refined carbohydrate by patients with Crohn's disease in Tel-Aviv-Yafo. Postgrad Med J 1980; 56: 842-6.

88 Jarnerot G, Jarnmark I, Nilsson K. Sugar consumption in Crohn's disease, ulcerative colitis and irritable bowel syndrome. Scand J Gastroenterol 1982; 17: 352.

89 Thornton JR. Emmett PM. Heaton KW. Diet and ulcerative colitis. Br Med J 1980; 1: 293-4.

90 Kasper H, Sommer H. Dietary fiber and nutrient intake in Crohn's disease. Am J Clin Nutr 1979; 32: 1898-1901.

91 Penny WJ, Mayberry JF, Aggett PJ, Gilbert JO, Newcombe RG, Rhodes J. Relationship between trace elements, sugar consumption and taste in Crohn's disease. Gut 1983; 24: 288-92.

92 Tiomny E. Horwitz C, Graff E, Rozen P. Gilat T. Serum zinc and taste acuity in Tel-Aviv patients with inflammatory bowel disease. Am J Gastroenterol 1982; 77: 101-4.

93 Kasper H, Sommer H. Taste thresholds in patients with Crohn's disease. J Hum Nutr 1980; 34: 455-6.

94 Heaton KW, Thornton JR, Emmett PM. Treatment of Crohn's disease with an unrefined carbohydrate, fibre rich diet. Br Med J 1979; 2: 764-6.

95 Brandes JW. Lorenz-Meyer H. Zuckerfreie Diat: Eine neue Perspektive zur Behandlung des Morbus Crohn? Eine randomisierte, Kontrollierte Studie. Z Gastroenterol 1981; 19: $1-12$.

96 Whorwell PJ. Holdstock G, Whorwell GM, Wright R. Bottle feeding, early gastroenteritis and inflammatory bowel disease. Br Med J 1979; 1: 382.

97 Storgaard L, Bischoff N, Henriksen FW, Fischerman K, Jarnum S. Survival rate in Crohn's disease and ulcerative colitis. Scand J Gastroenterol 1979; 14: 225-30.

98 Mayberry JF. Dew MJ, Morris JS, Powell DB. An audit of Crohn's disease in a defined population. J R Coll Physicians Lond 1983; 17: 196-8.

99 Malchow H. Riker U, Dietz K. Lebenserwartung bei Morbus Crohn. Lebensversicherungsmedizin 1981; 33: 27-30.

100 Weterman IT. Course and long-term prognosis of Crohn's disease. Leiden: MD Thesis.

101 Truelove SC. Peña AS. Course and prognosis of Crohn`s disease. Gut 1976; 17: 192-201.

102 Prior P. Gyde S. Cooke WT, Waterhouse JAH, Allan RN. Mortality in Crohn's disease. 
Gastroenterology 1981; 80: 307-12.

103 Prior P, Fielding JF, Waterhouse JA, Cooke WT. Mortality in Crohn's disease. Lancet 1970; 1: 1135-7.

104 Weedon DD, Shorter RG, Ilstrup DM, Huizenga KA, Taylor WF. Crohn's disease and cancer. N Engl J Med 1973; 289: 1099-103. 